\title{
"The Double Privilege of Athens and Jerusalem": The Relationship between Philosophy and Religion in the Works of Paul Ricoeur
}

\begin{abstract}
"[I must] face, if the time is left to me, the question...concerning the relation between the arguments of philosophical and non-philosophical sources; more specifically, the question of the conflictual-consensual relation between my philosophy that refuses the absolute and my biblical faith that is nourished by exegesis more than by theology." 1
\end{abstract}

The Intellectual Autobiography of Paul Ricoeur

\begin{abstract}
Ricoeur's autobiographical works, written mainly in the final decade of his life, have proven to be a valuable if contentious resource. On the one hand, they bring into focus the tense relationship between philosophical and religious thought in Ricoeur's corpus; on the other, they offer new insights into the broader interdisciplinary implications of his philosophy. This paper considers the recent interpretations and potential misconceptions associated with these late publications. I argue that, contrary to recent critiques, these autobiographical works are neither a deviation nor denunciation of his earlier philosophical approach. Rather, they offer a context to better understand Ricoeur's ambitious hermeneutical project of the 1970s.
\end{abstract}

\section{Introduction}

The boundaries between philosophy and religion have for decades been at the center of Ricoeur scholarship. ${ }^{2}$ It was, however, a subject that Ricoeur himself came to explore

\footnotetext{
${ }^{1}$ Paul Ricoeur, 'The Intellectual Autobiography of Paul Ricoeur', in The Philosophy of Paul Ricoeur (Chicago: Open Court Trade and Academic Books, 1995), p. 53.

${ }^{2}$ Recent contributions to this area of study include the proceedings from the 2008 Leuven conference 'Paul Ricoeur: Poetics and Religions': J. Verheyden, T.L. Hettema \& P. Vandecasteele (eds.), Paul Ricoeur: Poetics and Religion (Leuven: Uitgeverij Peeters, 2011). Other recent publications include: David Stewart, 'Ricoeur on Religious Language', in The Philosophy of Paul Ricoeur (Chicago: Open Court, 1995); Dan R. Stiver, Theology after Ricoeur: New Directions in Hermeneutical Theology (London: Westminister John Knox Press, 2001); Werner G. Jeanrond, 'Hermeneutics and Revelation', in Memory, Narrativity, Self and the Challenge to Think God: The Reception within Theology of the Recent Work of Paul Ricoeur, (eds.) P. Kenny and M. JunkerKenny (Münster: Lit Verlag, 2004); Boyd Blundell, Paul Ricoeur between Theology and Philosophy: Detour and Return (Bloomington: Indiana University Press, 2010); Henry I. Venema, 'The Source
} 
with some hesitancy. Throughout his career, Ricoeur published on a variety of Christian themes alongside his major philosophical works. Most notably, he returned to questions surrounding religious symbolism and biblical textuality, and often incorporated biblical passages as literary examples in his non-religious writings. Yet, despite an abiding interest in Christian themes and biblical language, he held to the belief that religion and philosophy were separate "manners of thinking" whose distinctiveness should be maintained within the academic sphere. ${ }^{3}$

In many ways, Ricoeur's corpus is defined by this methodological separation between philosophical and theological studies. Any examinations carried out within one discipline tended to be treated in isolation from those in the other, and he rarely allowed for overlap in terms of secondary sources or theorists cited. Exceptional periods, such as the 1970s, ${ }^{4}$ saw these two focuses brought closer together though, even then, Ricoeur was attentive to the dangers of conflating the two spheres.

Despite staying true to this self-imposed rule of separation, it was only later in his career that he spoke openly about his attempts to balance these two seemingly incompatible interests. Between 1990 and 2004, Ricoeur released a collection of personal, autobiographical publications centered around the distinction between philosophy and religion. These works outlined the rationale behind his methodological stance and reflected on the dangers of such a rigid approach. As we shall see, subsquent scholarly criticism was quick to proclaim that Ricoeur had turned a corner, of sorts, and abandoned his earlier resolve "not to mix" disciplines. ${ }^{5}$

In the following discussion, I argue that the attempt to reconcile philosophical and religious interpretation occurred not only at the later stages of Ricoeur's career, but was a prominent concern throughout his oeuvre. By looking at Ricoeur's autobiographical publications in relation to his earlier writings, it can be established that (far from deviating from his previous stance) his later works both synthesize and build upon his earlier studies, particularly those of the 1970 s. $^{6}$

of Ricoeur's Double Allegiance', in A Passion for the Possible: Thinking with Paul Ricoeur (New York: Fordham University Press, 2010).

3 Paul Ricoeur et al., Critique and Conviction: Conversations with Francois Azouvi and Marc De Launay (New York: Columbia University Press, 1998), p. 142.

${ }^{4}$ Though the term 1970 s is used, the works from this period were more precisely published between 1968 and 1979.

${ }^{5}$ Ricoeur, 'The Intellectual Autobiography', p. 13.

${ }^{6}$ See footnote 10 for list of relevant publications from this period. 
The second part of the discussion will look more closely at Ricoeur's hermeneutical publications from 1968 to 1979. For, more than at any other point in his career, this was when Ricoeur's previously separate philosophical and theological projects interconnected. It shall be shown that, while Ricoeur would never renounce the belief that philosophy and religion derived from different "sources", and thus ought to be treated distinctly, he likewise believed that a reconciliation of sorts could be forged between the two through the study of language and discourse.

\section{A “Methodological Separation": Early Encounters between Philosophy and Religion}

Already in his first publications on freedom and the will in 1935, Christian subject matter figured prominently in Ricoeur's work. ${ }^{7}$ During the initial period of his career (leading up to the mid-1960s) he published a number of isolated studies on the nature of Christianity within social and historical contexts. Due to his close association with the Christian philosopher Gabriel Marcel, it was hardly surprising that both his religious and non-religious writings regularly incorporated biblical passages as textual exemplars.

Despite his abiding interest in Christian anthropology and religious language, Ricoeur's major output during the first phase of his career was marked by forays into a number of secular subject areas and disciplines. While religious themes and biblical passages regularly appeared in his work, he tended not to conflate his Christian beliefs and his philosophical thought. ${ }^{8}$ In his early corpus, biblical content was often presented as one possible literary example among many, and his engagement with biblical scholarship was muted. Furthermore, he appeared to eschew the possibility that his own examinations of language and literature might somehow inform a contemporary theological understanding of religious language. He regularly asserted that any contributions he made to the study of religion stemmed from his orientation as a philosopher and not as a theologian. ${ }^{9}$

Ricoeur's advancement into the sphere of biblical hermeneutics in the 1970s marked a

\footnotetext{
71935 publications falling within the category of anthropology of religion include: Paul Ricoeur, 'L'appel de l'action. Réflexions d'un étudiant protestant' in Terre nouvelle (Paris: Organe des chrétiens révolutionnaires , 1935) and Paul Ricoeur, 'Un livre d'André Philippe : le christianisme et la paix' in in Terre nouvelle (Paris: Organe des chrétiens révolutionnaires, 1935)

8 Paul Ricoeur, 'The Intellectual Autobiography of Paul Ricoeur', pp. 13 \& 25.

9 See: Paul Ricoeur, 'Conference Round Table Discussion' in La Révélation (Brussels: Facultés universitaires Saint-Louis, 1984) p. 228.
} 
watershed in the development of his thought. On the surface, this was a natural progression from his recent work on primary religious symbolism from the early 1960s. Yet, in a break from his earlier stance, it also signaled an intention to explore the common ground between philosophy of language and biblical theology - an area of study that he had previously shunned.

During this period, Ricoeur's textual hermeneutics evolved through a dialectic of general hermeneutical theory and biblical exegesis. ${ }^{10}$ While his work was marked by an effort to explore the points of convergence between the philosophical and theological domains, the distinctiveness of each discipline was maintained throughout. Publications in the 1970s tended to fall into three separate categories between these poles: structuralist examinations of discourse, metaphorical language and text (where few to no biblical sources or scholarship were cited); theological studies into the relationship between biblical hermeneutics and New Testament exegesis; and inter-disciplinary analyses of the potential application of general hermeneutical resources (including critical theory, structuralist linguistics and ontology) to the study of religious language.

Notably, Ricoeur's 1970s corpus comprised the majority of Ricoeur's religious publications. As significantly, it appeared to situate these discussions within his philosophical framework of the time. This, on the surface, challenged the rigid rule of separation that he had maintained both prior to the 1970s and after. The about-turn in Ricoeur's methodological stance was noted and regularly queried by his colleagues and collaborators. It was, however, not until late in his career that Ricoeur discussed in any detail the underlying rationale that gave rise to this exceptional body of work.

\section{Intellectual Memoirs and Recent Reception}

\footnotetext{
${ }^{10}$ Ricoeur's hermeneutical publications between 1968 and 1979 followed two paths. His 'philosophical' studies were geared towards the examination of discourse and the explication of meaning through text. These works can be understood as Ricoeur's "general hermeutical theory" and include the articles compiled in: [Parts 1-4 of] Paul Ricoeur, Le Conflit des interprétations. Essais d'herméneutique (Paris: Éditions du Seuil, 1969); Paul Ricoeur, Hermeneutics and the Human Sciences (Cambridge: Cambridge University Press, 1981); Paul Ricoeur, Du texte à l'action, Essais d'herméneutique II (Paris: Éditions du Seuil, 1986). The second facet of his hermeneutical project looked to characterize biblical language as a particular form of discourse; these works make up Ricoeur's "regional hermeneutical theory". The most expansive of these studies is Paul Ricoeur, 'Biblical Hermeneutics', Semeia 4 (Missoula: Scholars Press, 1975). Many of his other publications on biblical discourse from this period are compiled in: [Part 5 of] Paul Ricoeur, Le Conflit des interprétations. Essais d'herméneutique; Paul Ricoeur, Figuring the Sacred: Religion, Narrative and Imagination (Minneapolis: Fortress Press, 1995).
} 
Beginning in the 1990s, Ricoeur and his contemporaries set about to develop an intellectual history of his thought. The result was a mixed assortment of works ranging from interviews and round-table discussions to journal articles. These publications (appearing between 1990 and 2004) were centered on a common theme, the origins and development of Ricoeur's own philosophy. While rarely presented as such, this collection of five works can be seen to comprise Ricoeur's intellectual memoirs. They include: "Introduction: A Question of Selfhood" in Oneself as Another (1990); "The Intellectual Autobiography of Paul Ricoeur" in The Philosophy of Paul Ricoeur (1995); Critique and Conviction (1998); Owl of Minerva (2004); "Roundtable Discussion: Paul Ricoeur and Questioners" in Memory, Narrativity, Self and the Challenge to Think God (2004). While "The Intellectual Autobiography of Paul Ricoeur" is the centerpiece of these "narrative reflections", the four other works from this period both supplement and expound upon the subject matter covered in it.

While the scope of these works is vast, the discussion regularly returns to key autobiographical topics. For instance, Ricoeur addresses his relatively late inclination towards philosophical study, how the social and academic pressures of post-war France affected the development of his philosophy and, finally, his life-long struggle to reconcile critical analysis and religious reflection. Since Ricoeur's death, these publications have provided scholars with a fuller picture of the intellectual climate and historical debates in which he operated at various points of his career. It is, however, his candid discussions on the "dual orientation" of his work - towards philosophy on the one hand and religion on the other - that have generated the greatest debate and led to considerable confusion.

A principal theme that runs through many of the $1990 \mathrm{~s}$ publications is the epistemological and hermeneutical differences between philosophical and religious 'discourse'. Ricoeur initiates the discussion by offering his personal observations on how he first perceived the tension between philosophical and theological study in his native France. He speaks of his early encounters with university faculties in the 1930s, and how he observed a long-standing predilection to keep philosophical study autonomous from the influence of other disciplines. ${ }^{11} \mathrm{He}$ emphasizes the tension that

\footnotetext{
11 While the term "autonomous" can be interpreted in a variety of ways, Ricoeur is here suggesting that philosophy is an "independent" or "self-sustaining" modality of thought (Ricoeur, 'The Intellectual Autobiography', pp. 5-6). For further discussion on the relationship between faith and reason (or the "faith-reason dilemma") in the works of Paul Ricoeur, see: Dan R. Stiver, Theology after Ricoeur: New Directions in Hermeneutical Theology, pp. 220-234; Eric Crump,
} 
existed at the time between philosophical and theological disciplines in particular, characterizing their fraught relationship as a war of sorts, which as a young academic he was conscripted into: "It was in this way that I learned, during my years of apprenticeship at the University of Rennes...to conduct an internecine war, from one armistice to the next, between faith and reason, as we used to say then."12

Of particular interest to current scholarship are Ricoeur's accounts of having had his philosophical integrity questioned in his formative teaching years (as a lecturer in Paris) due to the religious tenor of his work. In several instances he recounts being branded a "crypto-theologian" by the philosophical academy in the early 1960s, as the mood changed towards atheism and the religiosity of his work became less palatable. ${ }^{13}$

Building upon the groundwork of 0 . Mongin, ${ }^{14}$ several contemporary scholars have reasoned that it was because of these social and academic pressures that Ricoeur had adopted his dichotomous approach to philosophical and religious investigation. For them, the 1960s academic censure was the decisive stimulus which compelled Ricoeur to de-theologize his philosophical output and, in the following decades, maintain a strict separation between the two bodies of work. They further suggest that, shortly before his death, Ricoeur came to denounce the methodological separation between the disciplines that he had maintained. Within recent scholarship, these viewpoints are most succinctly presented by D. Stiver:

Even though Ricoeur was reticent about his own theological influences in philosophy, it is clear at this point that Ricoeur's philosophy is at least "friendly" to Christian theology; in his own words, it provides an "approximation" to theological reflection. Moreover, his own late remarks reveal some change of mind about the clear demarcation that he sought...This separation was likely related to his context in France where he had to fight to overcome a tendency to see his Christian commitments as undermining his reputation as a philosopher. As he puts it, however, in a later interview, "I no longer find such conceptual asceticism tenable". 15

\footnotetext{
"Between Conviction and Critique: Reflexive Philosophy, Testimony, and Pneumatology" in Ricoeur As Another: The Ethics of Subjectivity (Albany: State University of New York Press, 2002), pp. 178-181.

12 Paul Ricoeur, 'The Intellectual Autobiography of Paul Ricoeur', p. 6.

13 Paul Ricoeur et al., 'Roundtable Discussion: Paul Ricoeur and Questioners', in (ed. Maureen Junker-Kenny and Peter Kenny) Memory, Narrativity, Self and the Challenge to Think God: The Reception within Theology of the Recent Work of Paul Ricoeur (Münster: Lit Verlag, 2014), p. 203.

${ }^{14}$ Olivier Mongin, 'Paul Ricoeur' (Paris: Edition du Seuil, 1984)

${ }^{15}$ Daniel Stiver, 'Systematic Theology after Ricoeur', Journal of French and Francophone Philosophy 16 (2006): p.158.
} 
Stiver takes the view that the friction between Ricoeur and his academic peers was the primary motive for adopting a "clear demarcation" between philosophical and theological thought. He further states that this manner of separating the two disciplines was reappraised, and ultimately rejected, by Ricoeur himself towards the end of his life.

The basis of Stiver's causal argumentation ${ }^{16}$ hinges on Ricoeur's use of the phrase "conceptual asceticism" seen in the embedded quotation above. In Stiver's view, Ricoeur is using this cryptic term to describe his own separation (or "demarcation") between the philosophical and theological spheres, in response to the academic censure he endured. This, however, is a rather loose interpretation of the original source material.

Ricoeur initially uses the term "conceptual asceticism" in an exchange with Richard Kearney (published in Owl of Minerva). In looking at the excerpt from the original 2004 publication, the subject under discussion is not Ricoeur's own analytic approach at all. Rather, Ricoeur is deliberating on the historical relationship between ontology and religion - and the blanket rejection of medieval "onto-theo-logy" by $20^{\text {th }}$ century continental philosophers (an approach that Ricoeur himself had previously condoned):

My thought here is not so removed from certain religious and biblical issues as my standard policy of 'conceptual asceticism' might have been prepared to admit in the past. I am not sure about the absolute irreconcilability of the God of the Bible and the God of Being (understood with John Nabert as 'primary affirmation' or with Spinoza as 'substantia actuosa'). The tendency of modern French thought to eclipse the Middle Ages has prevented us from acknowledging the very rich attempts to think God and being in terms of each other. I no longer consider such conceptual asceticism tenable. ${ }^{17}$

A similar position to Stiver's is presented in the 2013 publication by C. M. Gschwandtner. In the part entitled "A Controlled Schizophrenia" Gschwandtner considers the shortcomings of Ricoeur's methodological division between his philosophical body of work and his biblical writings. She argues that Ricoeur's dualistic approach runs contrary to the analytic methods routinely used in his philosophical investigations (where conceptual distinctions were successfully broken down "to allow for dialogue between opposing positions"). ${ }^{18}$ Gschwandtner holds that in Ricoeur's work

\footnotetext{
16 This reading is here defined as "causal" due to Stiver's use of a "causal chain", whereby Ricoeur's "demarcation" of philosophical and religious thought is seen to relate directly to the sociological pressures he was under from the French philosophical establishment.

${ }^{17}$ Richard Kearney, On Paul Ricoeur: The Owl of Minerva (Aldershot: Ashgate Press, 2004), p. 169.

${ }^{18}$ Christina M. Gschwandtner, 'Paul Ricoeur: A God of Poetry and Superabundance' in Postmodern Apologetics (New York: Fordham University Press, 2013), p. 101.
} 
(up to the 1990s) philosophical and religious discourse types are held in perpetual opposition, with any potential crossover left unexplored. This method of artificial separation is seen to be inadequate to "resolve the dichotomy"19 between the two diverse modes of discourse:

To some extent, the watertight division between Ricoeur's strictly philosophical work and his writings on biblical hermeneutics might well be artificial and misleading. One might suggest that the two discourses inform each other much more meaningfully than Ricoeur often admits. ${ }^{20}$

As with Stiver, Gschwandtner conducts her analysis of Ricoeur's earlier corpus based entirely upon his late autobiographical publications - particularly Critique and Conviction. Like Stiver, she also postulates that Ricoeur's approach was put in place in order to defend his philosophical endeavors from the charge of a "crypto-theological reading" and that, in his later career, he came to recognize the stark "and in many ways false" opposition between philosophical analysis and theological reflection. ${ }^{21}$

Without delving too deeply into the merits of causal analysis as such, we can observe how the readings adopted by Stiver, Gschwandtner et al., while initially compelling, begin to fray under close scrutiny. This is not least because they run contrary to the views regularly expressed by Ricoeur himself throughout his career, as well as in those late autobiographical publications where he directly discusses his analytic approach and the reasons for it.

Of the works that comprise Ricoeur's memoirs, the most comprehensive and often least cited is the "Intellectual Autobiography of Paul Ricoeur". Unlike the transcribed interviews and round-table discussions which have garnered much attention over the past decade, in this work Ricoeur carefully considers both the benefits and limitations of the autobiographical genre. It also provides a detailed, chronological summary of the development of his thought throughout his professional career. On the subject of his methodological approach, this work offers valuable insights.

Contra the causal reading outlined above, Ricoeur clarifies that his decision not to conflate philosophical and religious thought originated well before the academic censure of the 1960s. Rather, he saw his path as having been determined decades before

\footnotetext{
${ }^{19}$ Ibid., p. 101.

${ }^{20}$ Ibid., p. 96.

${ }^{21}$ Ibid., p. 97.
} 
(in the 1930s) when, as a student, he was left unconvinced by the efforts of his contemporaries to amalgamate the study of philosophy and religion. Using the analogy of the "armistice", Ricoeur describes his nascent desire to explore the common ground between rationality and spirituality, while maintaining the theoretical integrity of each:

Today I recognize the mark of one of these armistices in the master's thesis I wrote during the 1933-34 academic year on the Problem of God in Lachelier and Lagneau. I found it intellectually satisfying that thinkers so taken with rationality and so concerned with the autonomy of philosophical thinking had granted a place for the idea of God, as such, in their philosophy, while at the same time neither encouraged me to make any sort of amalgamation between philosophy and biblical faith. This is why I have spoken of an armistice rather than an alliance. ${ }^{22}$

In this work, Ricoeur regularly reflects on his resolution to not combine philosophical and biblical disciplines (also termed "sources" or "genres"). He characterizes his "rule of strict separation" 23 as a basic imperative that he adopted early, and remained faithful to throughout his career. Indeed, he holds that while his research interests tended towards the confluence of philosophy and religion, when teaching in France during the 1950s and 1960s, he was never himself tempted to write a definitive work in this area:

As for the poetics of Transcendence, this was never written, if by this title one expects something like a philosophy of religion, for lack of a theological philosophy. My primary concern, which has never wavered, not to mix genres together has instead drawn me closer to the notion of a philosophy without an absolute... Any reflection on the status of a subject who is summoned and called to self-scrutiny must, therefore, be sought in my efforts at biblical exegesis. ${ }^{24}$

Ricoeur clarifies that throughout his career he sought to avoid instances where theological paradigms might be construed either as a by-product of, or an appendix to, a given philosophical argumentation. Ricoeur cites his late (1990) publication, Oneself as Another, as a clear example of where the final version was amended to avoid a "mixing" of the two disciplines: "I did not include these two [religious] lectures in Oneself as Another, in order to remain faithful to the old pact I had made that the non philosophical sources of my conviction would not be mixed together with the arguments of my philosophical discourse." 25

If, as Ricoeur suggests, his determination to maintain the distinctiveness of philosophy

\footnotetext{
${ }^{22}$ Ricoeur, 'The Intellectual Autobiography', p. 6.

${ }^{23}$ Ibid., p. 25.

24 Ibid., p. 13.

25 Ibid., p. 50.
} 
and theology was neither motivated by the norms of the French academy nor by the critical reception of his work, why was this "imperative" put in place? In the second part of our discussion, it shall be shown that Ricoeur's methodology derived from his longstanding belief that Western epistemology is founded on the convergence of two very different traditions: Hellenistic rationality and Hebraic faith. What's more, we shall observe how Ricoeur tailors his analytic approach towards safely exploring the complex hermeneutical relationship that, he believes, exists between these two separate modes of perceiving reality.

\section{Athens and Jerusalem}

Starting with Ricoeur's publications from the 1950s, philosophy and religion were always characterized as separate epistemic traditions that derived from distinct geographical centers (Greece and the Near East respectively). At the early stages of his career, the two were characterized in the most general terms with emphasis placed on their different origins and defining features. His studies tended to present the two traditions as relating to one another only in as much they represented the 'dualheritages' of Athens and Jerusalem, whose historic "encounter" had formed the foundation of Western thought.

There are relations of "proximity" and "distance" that belong inescapably to the structure of our cultural memory. Hence, the privilege of "proximity" of Greek and Jewish cultures; these two cultures, which would contain nothing exceptional for an eye not situated anywhere in particular, constitute the first stratum of our philosophical memory. More precisely, the encounter of the Jewish source with the Greek origin is the fundamental intersection that founds our culture. The Jewish source is the first "other" of philosophy, its "nearest" other; the abstractly contingent fact of that encounter is the very fate of our occidental culture....This is why the history of the consciousness of fault in Greece and Israel will constantly be our central point of reference; it is our "nearest" origin, in the spiritual economy of distance. The rest follows from the double privilege of Athens and Jerusalem: everything that, step by step, has contributed to our spiritual genesis belongs to our investigation, but along the lines of motivation that are expressed by "near" and "far". ${ }^{26}$

In early texts such as Symbolism of Evil, Ricoeur asserted that it was the coming together of these cultural outlooks that had informed, if not determined, the direction of Western epistemology. From the outset, however, Ricoeur was mindful to highlight which tradition he was following with regard to his own studies. His publications from the 1940 s to the 1960s were firmly situated within either the sphere of philosophy or

26 Paul Ricoeur, The Symbolism of Evil (New York: Harper \& Row, 1955), p. 20. 
theology, as he strove to adhere to the conventions that defined each epistemological strand. As previously noted, this segregation of the two disciplines was interpreted by critics as an attempt to maintain the purity of "philosophy qua philosophy", in line with the outlook of the French academy. ${ }^{27}$ In his autobiographical works, Ricoeur however stated that he was equally, if not more, concerned with maintaining the integrity of the theological tradition: "If I defend my philosophical writings against the accusation of crypto-theology, I also refrain, with equal vigilance, from assigning to biblical faith a crypto-philosophical function, which would most certainly be the case if one were to expect from it some definitive solution to the aporias that philosophy produces in abundance..."28

While this underlying resolve to not mix would be tested in later years, Ricoeur would never fully abandon it. As H. I. Venema (2010) notes, even when Ricoeur's outlook became more centered in language studies than epistemology, philosophy and religion would continue to be treated (from a methodological standpoint) as belonging to very different and, often, incompatible modes of thought: "For Ricoeur, philosophy and religion have always embodied two different styles or orientations of thinking, rooted in different texts that are subject to a hermeneutic of critical suspicion and affirmation."29

The late 1960s would see an easing of this rigid separation between his philosophical and religious inclinations. Though Ricoeur would never renounce the belief that the two disciplines originated from different sources (and should thus not be conflated), he increasingly sought to examine the relationship between their respective traditions. ${ }^{30}$ Within the constraints of his self-imposed imperative, his work of the 1960s began to consider the points of overlap between philosophical and biblical subject matter.

${ }^{27}$ Henry I. Venema, 'The Source of Ricoeur's Double Allegiance', p. 63.

28Paul Ricoeur, 'Introduction: A Question of Selfhood', in Oneself as Another (Chicago: University of Chicago Press, 1990), p. 24.

29 Venema, 'The Source of Ricoeur's Double Allegiance', p. 64.

30 The term "sources" in Ricoeur's work is knowingly appropriated from Paul Tillich's usage. It designates on the one side the dogmatic interpretation of biblical writing and on the other the non-dogmatic interpretation of human experience. Ricoeur would employ this term in two capacities within his work of the 1970s: first, as discussed here, it is used to differentiate between the Hebraic and Hellenistic epistemological traditions; secondly, it is used to identify the internal tension within religion itself - between the more static ecclesiastical (or magisterial) interpretation of scripture and the more variable interpretation of religious texts and religious experience held by an individual: "It is well known that Paul Tillich initiated this model with his method of correlation. For my part I readily assume this concept, if it only designates the formal task of relating the two "sources" of theological discourse (the meanings displayed by religious texts as interpreted in one of the great Christian traditions and the meanings displayed by ordinary human experience) to one another." Paul Ricoeur, 'Biblical Hermeneutics', p. 131. 
Ricoeur's late autobiographical publications cite several reasons for this observable change in tack. Firstly, he believed that contemporary academia was failing to explore the rich middle ground between "rationality and spirituality", as he termed it. In dialogue with Richard Kearney, Ricoeur laments how the Judeo-Christian tradition and Greek rationality were consistently held apart by $20^{\text {th }}$ century thinkers in a false dichotomy of sorts. ${ }^{31}$ While it was certainly prudent to maintain the distinctions between philosophical and theological modes of study, it was quite another thing to ignore the historic association that had developed between the two traditions.

$20^{\text {th }}$ century scholarship needed to redress this anti-religious bent, whereby theological study was systematically marginalized from so called rational disciplines. New "models of reconciliation" were needed with a view to establishing how religious reflection relates to other disciplines within the contemporary academic landscape. ${ }^{32}$ In practical terms, a "model of reconciliation" denotes a shared academic field or subject area situated between the two disciplines. However, by considering the ways in which philosophy and theology could individually contribute to a shared field of study, Ricoeur believed that the longstanding divisions between the two spheres could be overcome. In this respect, the study of language (with its syntax, literary structures and modes of reception) was seen as a mediating point, where religious inquiry and philosophical rationality inform one another:

What becomes apparent through all these diverse writings is the idea of an analysis of biblical language that ties together the diversity of the ways of naming God with that of the literary "genres" employed in the biblical canon. In this way, remaining faithful to my rule of strict separation, I directed my undistracted attention to the understanding belonging to faith, in an intimate dialogue between "philosophical hermeneutics and biblical hermeneutics".33

Though it was via his work in structural linguistics and literary theory that Ricoeur came to identify language as an apt means of reconciliation, he quickly determined that hermeneutics (rather than linguistics) was the more suitable field in which to bring the two disciplines together. Modern linguistics, stemming from the work of de Saussure was, for Ricoeur, was far too concerned with the internal relationships between

\footnotetext{
${ }^{31}$ Richard Kearney, Debates in Continental Philosophy: Richard Kearney in Conversation with Contemporary Thinkers (New York: Fordham University Press, 2004), p. 116.

$32 \mathrm{Ibid}$, p. 116: "From the eleventh century onwards we find models of reconciling reason and religion - in Anselm, for example - and the Renaissance confirms this primary synthesis of rationality and spirituality. If it is true that the rationality of scientific positivism has divorced itself from spirituality, there are many signs today that we are searching for new forms of connection."

${ }^{33}$ Ricoeur, 'The Intellectual Autobiography', p. 25.
} 
linguistic signs and structures, as opposed to how language relates to objects and actions in the real world. Hermeneutics, with its prioritization on traditions of interpretation and the reception of the meaning of written texts, had the benefit of being an inherently philosophical enterprise that nonetheless shared many of the concerns of biblical studies.

The fact that I relate to things by means of signs is already the first stage of the hermeneutical relation. This explains why there has been a surge of renewed interest among modern scholars in respect of the term hermeneutics; this happened because they found that the term exhibits the twofold significance of: a) being tightly linked to exegesis in a technical sense; b) working towards the integration of the particular problem studied by exegesis within the general theory of language, significance, or signs. ${ }^{34}$

In placing the focus of his research on the interaction between philosophical hermeneutics and biblical studies, Ricoeur did not see himself as proposing a new area of study. Rather, he saw himself as reviving a rich line of inquiry that, until the early $20^{\text {th }}$ century, had been the basis for all hermeneutical study. In many of the texts from this period, Ricoeur attempts to contextualize his research within earlier hermeneutical debates, ranging from patristic to Romantic philosophy. In the work of Schleiermacher, in particular, Ricoeur identified a rich repertoire of resources that he believed contemporary hermeneutical scholars could build upon. ${ }^{35}$

In 1968 Ricoeur published his first, exploratory interdisciplinary study in the field entitled Les incidences théologiques des recherches actuelles concernant le langage. ${ }^{36}$ The significance of this publication, both for Ricoeur scholarship and the wider study of hermeneutics, is manifold. Firstly, it offered a blueprint of how the philosophical study of language relates to biblical exegesis by mapping the key points where general hermeneutics and biblical hermeneutics had historically overlapped.

Beyond this, Les incidences théologiques clearly established the two topics that would form the basis of Ricoeur's own hermeneutical project throughout the 1970s. On the one

\footnotetext{
34 Paul Ricoeur, Les incidences théologiques des recherches actuelles concernant le langage (Paris: Institut d'Études Oecuméniques, 1968), p. 19: "Le fait que je sois en relation avec les choses par le moyen de signes, c'est déjà la relation herméneutique première. Ce qui explique que les modern aient eu le goût de reprendre ce terme herméneutique, c'est qu'ils avaient un mot qui avait cette double portée : $a$ - un sens technique qui le rattache plus étroitement à l'exégèse. $b$ - cette visée de rattacher le problème particulier de l'exégèse à la théorie générale du langage, de la signification ou du signe." [Translation mine]

35 Ibid., p. 19-24: Ricoeur observes how linguistic concerns figure prominently in early biblical studies of the patristics (such as Augustine), as well as within medieval scholarship. It is however the work of Schleiermacher and the Romantics in the $1^{\text {th }}$ century which was seen to have instigated a more comprehensive dialogue between philosophy of language and biblical studies. ${ }^{36}$ See footnote 27 for full bibliographic reference.
} 
hand, he signals an intention to advance his earlier philosophical investigations of symbolism in the direction of $19^{\text {th }}$ and $20^{\text {th }}$ century hermeneutical theory, focusing specifically on the relationship between text and meaning. On the other hand, he indicates a separate move towards demonstrating how biblical studies can be enriched by a hermeneutical understanding of discourse.

Simply put, this little-known, but seminal, text introduces two separate, but interrelated, questions that Ricoeur's entire 1970s corpus would strive to answer:

1. Can language qua discourse offer a basis for the study of the human sciences?

2. To what extent does religious language (and specifically scripture) utilize unique rhetorical formulations?

The importance Ricoeur's 1968 text lies not only in that it anticipates a split focus in his later work - on the one hand towards philosophical hermeneutics and, on the other, towards biblical theology. In a break from his earlier stance, this publication acknowledges that it is possible to conduct concurrent, and at times comparative, analyses of philosophical and theological subject matter, so long as they are focused around a central and unifying hermeneutical theme. More so than in any previous work, the text presupposes that these two discrete fields of study, deriving from very different epistemological traditions, can stimulate and inform one another:

By choosing this topic for debate, one is likewise placed at a point of confrontation that lends itself to making proper use of the method of biblical theology. This relies to a large extent on the interpretation of such key words as covenant, flesh, sin, grace, etc. and also this key word around which the whole of hermeneutics somehow gravitates: the very word "God" itself keeps demanding a thorough reorganization of any other key word. So precisely identified, the subject matter is situated at the junction of parole hermeneutics with mot semantics: the speech of words. ${ }^{37}$

Les incidences théologiques set the groundwork for many of Ricoeur's later studies from this period, where general (or non-religious) hermeneutical approaches were used to

\footnotetext{
${ }^{37}$ Ricoeur, Les incidences théologiques, p. 7 [Translation mine]: "En choisissant ce champ de confrontation, on se place en même temps à un niveau qui se prête bien à discussion avec la méthode de la théologie biblique, qui est pour une large part une interprétation des mots-clés : alliance, chair, péché, grâce, etc...et aussi ce mot-clé autour duquel gravite en quelque sorte toute herméneutique, le mot même de Dieu qui, à chaque moment, requiert une réorganisation entière de tous le mots-clés. Le sujet s'est précisé ; il se trouve situé au point de croisement de l'herméneutique de la parole et de la sémantique du mot : la parole des mots."
} 
better understand biblical language. In his discussion of the Roman Catholic theologians M.D. Chenu in Part 1,38 Ricoeur observes how a contemporary hermeneutical examination of symbols can expose the close affinity between biblical discourse and the polysemic use of language.

Chenu postulated that, at an embryonic stage, religious language came to harness the semantic abundance of symbols in a way unique to other literary forms. Religious symbols (such as father, water, kingdom etc.) connote a variety of significations at the same time. This multiplicity of meaning can often obfuscate one's interpretation of a text. Chenu, however, noted that with scripture, the polyphony of language greatly enriched the semantic structure of the writing, rather than hampering the reader's understanding. Put another way, while the inexactness of meaning generated by symbols often presents an obstacle for the interpretation of the reader, in the case of biblical discourse it functioned as an effective rhetorical device:

In an example drawn from the chapter on symbolism in Father Chenu's Théologie au XII siècle, the author demonstrates that the great symbols of Western culture originating from Hebraism are certainly tied to a universal kind of symbolism. But beyond that, one immediately recognizes that...we are confronted with a flourishing of sense, whereby anything can be representative of anything else...[These symbols] worked their way into biblical tradition to signify, for example, the threat of chaos, destruction, the diabolism latent in human nature, because biblical narrative supplied an effective means to harness semantic multiplicity. This multiplicity of sense or polysemy - the kind of flourishing polysemy of wild symbolism - needs to be suppressed and limited and, following such limiting, it becomes functional. 39

Ricoeur's 1970s hermeneutical studies would incorporate this insight from Chenu. He would hold to the belief that the polysemy of symbolic language was a defining characteristic of biblical discourse, while stressing that the semantic abundance of biblical symbols is only "made operative within the economy of sense" that scripture

\footnotetext{
38 Marie-Dominique Chenu, 'La théologie au XIIe siècle', in Études de philosophie medieval 45 (Paris: Vrin, 1957)

${ }^{39}$ Ricoeur, Les incidences théologiques, p. 10 [Translation mine]: "Un exemple tiré de la "Théologie au XXII' siècle" du P. Chenu, (chap. sur le symbolisme) où il montre que les grands symboles de la culture occidental, symboles d'origine hébraïque, reposent certes sur un symbolisme universel mais tout de suite...nous nous trouvons en face de tout un foisonnement de sens, où tout peut signifier tout et n'importe quoi ; les mêmes symboles...ont pu être repris dans la tradition biblique pour signifier par exemple menace de chaos, destruction, diabolisme latent de la condition humaine parce qu'ils ont été pris dans le récitatif biblique comme étant le moyen de maitriser une multiplicité sémantique. Par conséquent, la multiplicité de sens, la polysémie, cette polysémie foisonnante du symbolisme sauvage doit être maitrisée et limitée et par le moyen de cette limitation va devenir fonctionnelle.
} 
provided. ${ }^{40}$ As importantly, however, Ricoeur would adopt Chenu's outlook that, when applied to the study of discourse, general hermeneutical theories could be used to enhance one's understanding of the mechanics of scripture.

\section{Philosophical and Biblical Discourse}

A key work from the 1970s that sought to expound on the themes from Les incidences théologiques is "Biblical Hermeneutics" (1975). In this work, Ricoeur moves his focus away from simply identifying which general hermeneutical resources could be used to augment the study of biblical texts; instead, he seeks to provide a context for his 1970s interdisciplinary project by exploring the historical interaction between philosophical and religious forms of discourse.

In "Biblical Hermeneutics" Ricoeur contends that any viable notion of discourse needs to commence by exploring the tension between "general" forms of discourse (typified by philosophical discourse) and specific or "particular" forms of discourse (typified by biblical discourse). ${ }^{41}$ He proposes that hermeneutics, as a discipline, mediates between the two poles of general and particular forms and that, far from developing in isolation from one another, each of these forms often influences, in quite palpable ways, the development of the other.

To exemplify this point, Ricoeur returns once again to the analogy of Athens and Jerusalem from his earlier writing. In a stark change from his position from the 1950s however (where he focused solely on the differences between these two epistemic outlooks) he here holds that the encounter between Hellenistic and Hebraic cultures had, over the centuries, led to a cross-fertilization of sorts between the two forms of discourse. In particular, he argues that elements of philosophical discourse had been transferred, at an incipient stage, into the make-up and interpretation of religious writing. These characteristics, in turn, became some of the defining features of biblical interpretation: "It is a contingent situation transformed into fate that the JudeoChristian culture occurred on the borders of the Greek world and to a certain extent within its zone of influence." 42

\footnotetext{
40 Ibid., p. 7.

${ }^{41}$ Philosophical discourse as a meta-discourse (or 'discourse about discourse') is seen as the general form. Biblical discourse with its distinctive hermeneutical rules and conventions is understood by Ricoeur as a particular form.

42 Ricoeur, 'Biblical Hermeneutics', p. 129.
} 
Shedding the generalizations from works such as Symbolism of Evil, Ricoeur here offers an in depth examination of the ways in which religious writing shows the influence of classical Greek conceptuality. The first of these is seen in how the articulations of religious beliefs within scripture came to appropriate philosophical terms and mode of expression. Basic religious tenets (such as the fundamental expressions of covenant in Judaism and salvation in Christianity) began to be articulated in conventional philosophical terms, with earlier Hebraic texts becoming re-interpreted through a lens of philosophical paradigms.

Christianity borrowed from Hellenism its forms of argumentation, and even its fundamental semantics. Such words as sin, grace, redemption, atonement, eternal life, etc. received their meaning through the mediation of philosophical concepts at the time and above all under the influence of some prominent problematics in the cultural world of the day; the concern for eternity in NeoPlatonic spirituality, for example. ${ }^{43}$

Another distinctive characteristic of biblical discourse, which Ricoeur saw as stemming from the influence of Hellenism, is the necessary shift from figurative to conceptual interpretation. Appropriating a pattern common in Hellenistic thought, it became the norm for the interpretation of religious writing to encompass two steps. Scripture would continue to be initially written and read, as with the earlier Hebraic texts, using highly figurative or symbolic language. The interpretation of those passages, however, would go through a secondary process, whereby the original text was understood and relayed in the more easily accessible form of a "concept". 44 For Ricoeur, this reduction of figurative language to theological concept was not an indigenous feature of early Hebraic exegesis. Rather, through the dissemination and adoption of Hellenistic rationality it came to be a defining trait of biblical discourse:

Religious language itself requires the transposition from "images" or rather "figurative modes" to "conceptual modes" of expression... At first sight this transposition may seem to be merely an extrinsic change, I mean, one superimposed from the outside. Figurative language seems compelled to take the route of the concept for a reason which is peculiar to Western culture. In this culture, religious language has always been exposed to another language, that of philosophy, which is the conceptual language par excellence... This explains why so many writings in both the Old and the New Testament express a certain influence of Hellenism. And it explains above all why the Christian Church was unable to elaborate a theological discourse without the help of Greek

\footnotetext{
43 Ibid., p. 129.

${ }^{44}$ It is unclear to what extent Ricoeur was involved with the 1970 s debates on the viability of the "classical theory of concepts". Within the parameters of this discussion, therefore, it shall be assumed that "concept" for Ricoeur implies a definitional structure of lexical terms.
} 
conceptuality. 45

Ricoeur intimates that on the basis of textual evidence, the adoption of philosophical rhetoric became more pronounced in the centuries leading up to the establishment of the Christian Church. This is evident by comparing the literary differences between the two Testaments within Christian scripture. Moving from the Old Testament to the New Testament, figurative language becomes supplanted as the dominant mode of expression. Though the Biblia Hebraica employs a number of rhetorical forms for the transmission of meaning, narrative is most prevalent. As we move into New Testament writing, and particularly when considering the letters of Paul, conceptual discussions overtake figurative formulations (such as psalms or narrative) as the dominant mode of expounding and exploring religious principles. As the abstract formulations of Greek prose are introduced into scripture, conceptual dialogue becomes an increasingly common attribute of biblical writing. This is particularly evident when comparing the first Greek translations of the Hebrew Bible in the $3^{\text {rd }}$ century BCE, with the ratified works of the New Testament canon in, or around, the $4^{\text {th }}$ century CE.

For Ricoeur, the incursion of philosophical constructs affected the Christian Church as much as Second Temple Judaism. What's more, early Christian readings were not as insulated by the traditions of interpretation that had been passed down through the rabbinic school. Due to this, Christian prose tended to be more engaged with conceptual discussion concerning the interpretation of the gospels as well as their relationship to Old Testament writings. 46

Ricoeur stresses, however, that not every facet of religious expression can be reformulated in conceptual form. He notes that key terms within scripture - for instance the ones that denote the divine - are hallmarks of the earlier Hebraic tradition, where the terms designate a multitude of significations referring to yet more significations (as articulated by Chenu). The variable nature of terms such as "God" is reminiscent of an earlier form of cultural symbol; the "density of meaning" which these terms offer is seen to hinder the process of conceptual reduction, thus allowing for the polysemic meaning to flourish. Within the framework of biblical discourse, which is comprised of a variety of literary genres rooted in different socio-political contexts, Ricoeur stresses that these loaded religious terms can only be understood through their variable usage throughout the expanse of the biblical canon. Due to this, religious language requires a variety of modes of reading, to account for both the more conceptual and more figurative

\footnotetext{
45 Ibid., p. 129.

46 Ibid., pp. 129-130.
} 
passages:

Thus the word God in Biblical texts receives its meaning from the convergence of several modes of discourse (narratives and prophecies, legislative texts and wisdom literature, proverbs and hymns) - as both the intersection point and the horizon which escapes each and every form-had to be absorbed in the conceptual space, to be reinterpreted in terms of the philosophical Absolute, as prime mover, first cause, Actus Essendi, Perfect Being, etc. Hence our concept of God belongs to an onto-theology, within which it keeps organizing the entire constellation of the keywords of theological semantics, but within a framework of meanings prescribed by metaphysics. ${ }^{47}$

Though Ricoeur's late autobiographical publications have stimulated considerable debate in recent years, a close reading offers insight into one of the richest, and least explored, periods of his oeuvre. Throughout his career, Ricoeur maintained a rigid methodological separation between his philosophical and religious writings. However, through the hermeneutical exploration of language and discourse, these two driving interests became aligned. Beginning in 1968, with the publication of Les incidences théologiques des recherches actuelles concernant le langage, through to the end of the 1970s, Ricoeur set out to explore the complex ("conflictual-consensual") relationship between philosophical and religious discourse. His studies of these contrasting forms would underpin his groundbreaking work throughout the 1970s (on textual hermeneutical theory and biblical theology) and the early 1980s (on narrative and historiography).

A foundation of his hermeneutical understanding already present in his 1968 publication was that figurative, or symbolic, language requires a different ("longer") route of interpretation to non-figurative language. To appeal immediately to the explicit meaning of figurative language - and to reduce the symbolism used within it to a conceptual derivative - was to short-circuiting the interpretative process. This principle would inform his explorations into the semantics of metaphor, and his critiques of Heiddeggerian/Gadamerian ontological hermeneutics. Within his more religiously based publications from this period, 48 it underpinned his argument that the

\footnotetext{
47 Ibid., p. 130.

48 See: Paul Ricoeur, "Philosophical Hermeneutics and Biblical Hermeneutics" in François Bovon and Grégoire Rouiller (eds.) Exegesis: Problems of Method and Exercises in Reading (Pittsburgh: Pickwick Press, 1978), pp. 321-339; Paul Ricoeur, "Toward a Hermeneutic of the Idea of Revelation", Harvard Theological Review 70 (1977), pp. 1-37; Paul Ricoeur, "Naming God", Union Seminary Quarterly Review 34 (1979): pp. 215-227.
} 
interpretation of biblical discourse relies upon a network of meaning forged through the intertextual bonds between the different biblical texts.

Through his study of biblical discourse, Ricoeur came to understand that the surplus of meaning created by figurative language is a hermeneutical tool rather than an obstacle that enriches 'poetic' forms of discourse. This would be the first, but not sole, instance where the implications of his studies into biblical discourse would impact upon his general hermeneutical understanding as well. 